\title{
Experimental study on transient response of fuel cell
}

\author{
Ameerul A. J. Jeman ${ }^{1}$, Naeem M. S. Hannoon ${ }^{2}$, Nabil Hidayat ${ }^{3}$, Mohamed M. H. Adam ${ }^{4}$, Ismail \\ Musirin', Vijayakumar V.6 \\ ${ }^{1,2,3,4,5}$ Faculty of Electrical Engineering, Universiti Teknologi MARA (UITM), Malaysia \\ ${ }^{6}$ School of Computing Science and Engineering, VIT University Chennai, India
}

\begin{tabular}{|c|c|}
\hline Article Info & ABSTRACT \\
\hline Article history: & This research work discusses a control strategy to enhance the transient \\
\hline Received Oct 16, 2018 & $\begin{array}{l}\text { response of the fuel cell and boost the real and reactive power flow from grid } \\
\text { connected to fuel cell. The current output of the fuel cell depends on the }\end{array}$ \\
\hline Revised Nov 15, 2018 & availability of hydrogen in the fuel cell stack, a battery bank is implemented \\
\hline Accepted Feb 4, 2019 & to supply the transient current and to prevent it from hydrogen saturation. \\
\hline & the total power is produced by the fuel cell by regulating its hydrogen input. \\
\hline Keywords: & A prototype of the system will be created to study a control scheme which \\
\hline Converter & regulates the current from an input source and a battery which is connected to \\
\hline dq-transformation & $\begin{array}{l}\text { a dc motor. The control philosophy is based on } \mathrm{d}-\mathrm{q} \text { transformation and } \\
\text { subsequently generating a reference signal that is tracked by an IGBT based }\end{array}$ \\
\hline Fuel cell & inverter. The speed of the motor is controlled using pulse with modulation. \\
\hline Transient & $\begin{array}{l}\text { The dynamic modeling of the standalone fuel cell that is connected to a dc } \\
\text { motor is carried out using MATLAB/SIMULINK platform. The simulation } \\
\text { results show that the control scheme works well, although the dynamic } \\
\text { response of the system can be improved. The testing carried on the prototype } \\
\text { proves that the concept works well, but a hydrogen control scheme should be } \\
\text { developed to improve the efficiency of the control scheme. }\end{array}$ \\
\hline
\end{tabular}

Copyright (ㅇ 2019 Institute of Advanced Engineering and Science. All rights reserved.

\section{Corresponding Author:}

Naeem M. S. Hannoon,

Faculty of Electrical Engineering,

Universiti Teknologi MARA (UiTM),

40450 Shah Alam, Selangor, Malaysia.

Email: hannoon.naeem@gmail.com

\section{INTRODUCTION}

As the demand of electricity increases, and the conventional method of generation electricity produces a lot of green houses gasses there is a great need for a new and cleaner way to produce electricity. This is the main reason of the increase of interest for distributed generation (DG). DG converts renewable energy such as wind, sunlight, hydrogen into electricity using wind turbines, photovoltaic cells, fuel cells and hydro turbines. DG have a lot of advantages, most of them are environmentally friendly, high efficiencies, remote generation, modular electricity generation, increased reliability, high power quality, uninterruptible power service, cost saving, on site generation and easy expandability, etc. [1] make it the best choice to generate electricity to fulfill the incense in demand.

The fuel cell based DG is the most attractive option because its extra benefits compared to other type of DGs. The advantages are high efficiency almost $30 \%$ to $65 \%$, multi fuel adaptability, almost zero emission, quiet operation, high reliability because of little moving parts and does not depend on climate conditions. Fuel cells generate electricity from an electrochemical reaction known as reverse electrolysis. Fuel cells are made out of three main segments which are sandwiched together that is the anode, the cathode and the electrolyte. Electrolyte on the other hand is a substance that contains free ions that make the substance electrically conductive. The hydrogen gas is supplied to the anode where it is oxidized positive 
hydrogen ions as shown in (1). Oxygen is supplied to the cathode where it is reduced as shown in (2). The overall equation that is shown in 3 show that the product of this chemical reaction is water and electricity. As long as the hydrogen and oxygen is supplied to each electrode the partial reactions will take place at each electrode and there will be continuous flow of current. A fuel cell can produce a voltage form $0.6 \mathrm{~V}$ to $0.7 \mathrm{~V}$ at full capacity. In order to supply a load that is more than $0.7 \mathrm{~V}$ a few fuel cells can be combined together to form a fuel cell stack to increase its capacity.

The one major disadvantage of fuel cells is, they cannot respond to student changes of load immediately. This is because the current produced by the fuel cell is proportional to the production of free electrons from the chemical reaction between hydrogen and oxygen. The time taken to produce hydrogen by the reformer is large; this affects the power output of the fuel cell. To overcome this problem an energy storage device such as a battery or ultra capacitor need to be integrated with the fuel cell as temporary energy storage element to supply power during transients of startup and student load changes.

The four main types of fuel cells are polymer electrolyte membrane or proton exchange membrane (PEMFC), molten carbonate (MCFC), phosphoric acid (PAFC) and the solid oxide fuel cell (SOFC). Solid Oxide Fuel Cell (SOFC) is used in fuel cell based distributed system because it can be used with a wide range of fuels which includes hydrocarbon. Due to its high operation temperature high efficiency power conversion can be achieved. SOFC systems have demonstrated among the highest efficiencies for power generation. It also has low air pollutant emission and low green house gas emission. These are few factors that make SOFC and attractive technology for stationary power generation in the range of few $\mathrm{kV}$ to few hundred $\mathrm{kV}$ [2].

K. Sedghigarchi and A. Feliachi in [2,3] have addressed the fuel-cell dynamic model, the gridconnected DGs, but their paper does not have energy storage devices for transient backup. Also a three-phase PWN inverter is not considered in these papers. Sung-Yeul Park [4] and M.Y.El-Shaker et al. in [5] described the control of real and reactive power of fuel cell DC feeding grid and isolated system respectively. They did not consider a source for backup during transient period. C.Wang in $[6,7]$ modeled the delay in fuel cell response due to hydrogen dynamics to transient change in load, in terms of an RC circuit at the output of $\mathrm{dc} / \mathrm{dc}$ converter.

In this paper the slow response of fuel cell caused by hydrogen dynamics is considered as integral part of fuel cell modeling. The efficient and economical operation of the fuel cell is achieved by restricting the utilization of hydrogen to upper and lower limits respectively. A simulation using the MATLAB/SIMULINK platform is used to develop the fuel cell and the control scheme in order to analyze the proposed system modeling and its control structure. A prototype of the current control scheme is also design and tested.

\section{RESEARCH METHOD}

\subsection{System modelling}

Fuel cell based DG are mead out of three main components. The components are Fuel processor, power generation unit, power processing unit. The Fuel processor converts the input fuel into hydrogen and other byproduct gasses. The hydrogen is then fed to the power processing unit that is the fuel cell. In the fuel cell the chemical energy is converted to electrical energy. In order to meet the power and voltage requirements based on application, fuel cell are connected together to form a stack. The power processing unit processes the dc output for the power processing unit to suit the requirement of the application. The dc output is converted to be a controlled dc power or may be ac power with frequency, voltage and power control. In following section each of the components is discussed in detail.

A storage element such as a battery need to be has to be connected in parallel with the fuel cell. This is because the fuel cell cannot respond to transient immediately. The charging and discharging rates of the battery should be within safe limits to ensure stability of the system. The dc/dc converter for the fuel cell is unidirectional and for the battery is bidirectional. Based on the configuration above there are two promising application of the system first is fuel cell stand alone system and second is fuel cell integrated with grid? In this paper only the first application is considered.

\subsection{A fuel cell modelling}

The time taken to convert the chemical energy to electrical energy in the power processing unit is known as electrical response time. The electrical response time of fuel cell is very small about a second [8], [9], it is modeled as a first-order transfer function. The process of converting input fuel to hydrogen that takes place in the reformer, significantly affects the dynamic behavior of the fuel cell because its response time is very high, from a few seconds to several minutes, when compared to electrical response time [10]. Because of this, the dynamics of the reformer need to be considered for dynamic modeling of the fuel cell. 
a. Reformer modeling: The hydrogen gas used in the fuel cell is produced by processing any hydrocarbon fuel such as natural gas, propane, and methanol and from electrolysis of water, which takes place in the reformer. The consideration of its dynamics is very important to make the simulation more aureate.

In [5], [11], [12] the authors have proposed the model of a reformer based on second odder transfer function to convert methane to hydrogen. It can be described as follow:

$$
\frac{q H 2}{\text { q methane }}=\frac{C v}{\tau^{1} \tau^{2} s^{2}+\left(\tau^{1}+\tau^{2}\right) s+1}
$$

Yoon-ho Kim et al. In [13], Ankur Goel, S. Mishra et al. in [14] modeled the reformer based on first odder transfer function as (5):

$$
\frac{q H 2}{q \text { methane }}=\frac{C v}{\left(\tau^{1}\right) s+1}
$$

where; $\mathrm{qH} 2=$ Hydrogen flow rate at the reformer outlet $(\mathrm{kmol} / \mathrm{s})$

qmethane=Methane flow at reformer inlet $(\mathrm{Kmols} / \mathrm{s})$

$\tau 1=\tau 2=$ Time constant $(\mathrm{s})$

$\mathrm{Cv}=\mathrm{Conversion}$ factor ( $\mathrm{Kmol}$ of hydrogen to $\mathrm{Kmol}$ of methane)

Rajkaruna et $a l$. in [15] shows that fuel processor approximated by first-order transfer functions is suitable for simulation propose. In this paper the fires-odder equation is used to model the reformer.

b. Modeling of hydrogen dynamics: The current that is produced but the fuel cell is created by the flow of electrons produced by chemical reactions at the anode and cathode terminals of the fuel cell. For a dc system the real power produced is the product of voltage and current. Hence, by controlling current the total power output of the fuel cell can be controlled. Current is produced by the chemical reaction between hydrogen and oxygen in the presents of an electrolyte, so by regulating the flow of hydrogen the power output of the fuel cell can be controlled. The hydrogen input to the fuel cell is to be controlled by the total current at the input of the dc motor, ifcref. The current then will be used to decide the hydrogen reference by considering the optimal

\subsection{DC/DC converters}

The fuel cell output voltage is not constant because it changes with the current. On the other hand, the current depends on the speed of the dc motor. In order to get constant voltage $\mathrm{dc} / \mathrm{dc}$ converters are used to regulate the output voltage of the fuel cell. The $\mathrm{dc} / \mathrm{dc}$ converter coverts the dc power output of fuel cell into dc power at a constant voltage. The fuel cells are connected in stacks to supply the required voltage and power levels. The boost dc/dc converter, which has very fast response time can be used to boost the low voltage output of the fuel cell. The $\mathrm{dc} / \mathrm{dc}$ converter and the fuel cell can be represented together as a controlled current source at constant voltage.

The $\mathrm{dc} / \mathrm{dc}$ converter that is used for the fuel cell is unidirectional, because it only allows current to flow out of the fuel cell. For the battery bidirectional dc/dc converter is used because the battery needs to supply power when there is a sudden increase of load and it has to absorb the power if there is a sudden decrease of load to maintain energy balance of the system. To make the dc/dc converter compatible with grid, an inverter is employed whose control based on PWM utilization in steady state operation of the fuel cell. The maximum current supplied that can be supplied by the fuel cell depends on the availability of hydrogen inside the fuel cell. The over utilization of hydrogen will cause hydrogen starvation which shortens the life of fuel cell and under-utilization will reduce the overall efficiency of the system. The ratio of input of oxygen to hydrogen for fuel cell is about 1.145 to keep the pressure in the fuel cell under safe limits during steady sate operations [8]. The fuel cell parameters have been given in appendix.

\subsection{Prototype modelling}

The main objective of the hardware prototype is to create a control scheme to control the input and battery current. The control scheme works by comparing the input and battery voltages. When the input voltage is higher than the battery voltage then the total current should be supplied by the input power source. But when the battery voltage is higher than the input voltage the battery will be supplied the additional current to full fill the load demand. The prototype is made out two main parts that is the power processing unit and dc motor. All the parts will be discussed in this section.

The power processing is main unit because it monitors the input voltage and battery voltage to determine the amount of current flow from the input and battery. The voltage regulator is used to represent the unidirectional $\mathrm{dc} / \mathrm{dc}$ converter of the fuel cell. A variable voltage regulator is used to regulate the input voltage. The output of the regulator can also be changed for testing purpose. The output of the voltage regulator is supplied to the voltage comparator which is used to represent the bidirectional dc/dc converter. 
The voltage comparator compares the input voltage and battery voltage and determines the amount of the current supplied by the battery.

The battery that is used in the prototype is a 9-Volt Nickel-Metal Hydride (NIMH) cell. The reason a rechargeable battery is used because it needs to supply power when there is a sudden increase of load and adsorb power when there is a sudden decrease in load to maintain energy balance of the system. In order to make sure the battery is fully charge it is connected to ca charging unit. A float charger is used because it can be connected for very long time without damaging the battery.

The prototype also has six meters to monitor the control scheme. There is also ac volt meter in the prototype but is it not used for testing in this paper. A volt meter and amp meter are used to monitor the input and battery current. An amp meter is also used to monitor their total current. The dc motor speed is controlled using pulse width modulation.

\section{RESULTS AND ANALYSIS}

This section presents the results and analysis of the study. The modeled system is tested using MATLAB with Field current-240V and Torque-5 Nm for DC motor. The initial speed of the motor is 500 $\mathrm{rad} / \mathrm{s}$. At one second, the speed is increased to $550 \mathrm{rad} / \mathrm{s}$. The system is studied for this transient change of load.

From Figure 1 it can be concluded when there is the battery will supply the transient load because the fuel cell cannot take the transient load. The fuel cell picks up and supplies the steady state part of the load. When there is a sudden change in speed the fuel cell output cannot increase its power immediately, so the battery takes care of the transients. As the output of the fuel cell increases the battery power decreases at the same rate to maintain the power balance of the system. Figure 2 shows the total, battery and fuel cell currents. On the other hand, Figure 3 and Figure 4 illustrate the situation when there is a sudden increase in the speed, the armature current also increases.

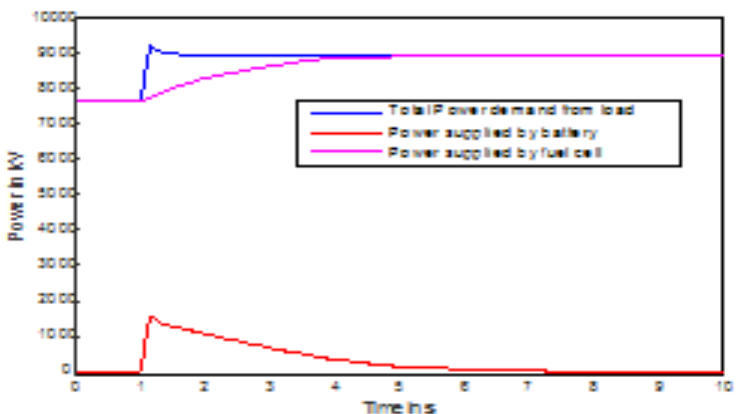

Figure 1. Total power demand by load, fuel cell power, battery power

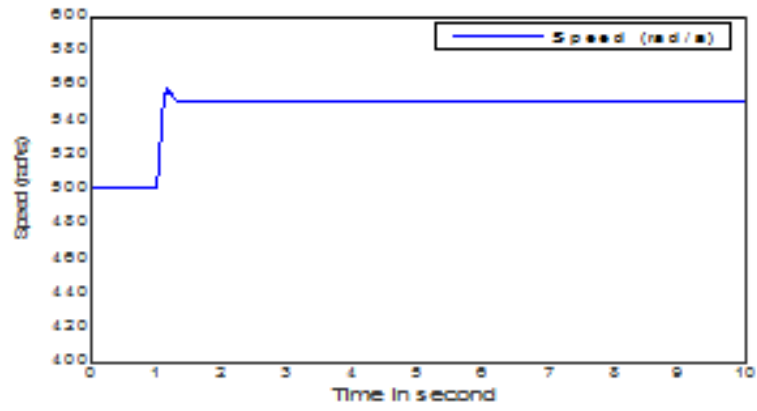

Figure 3. Motor speed

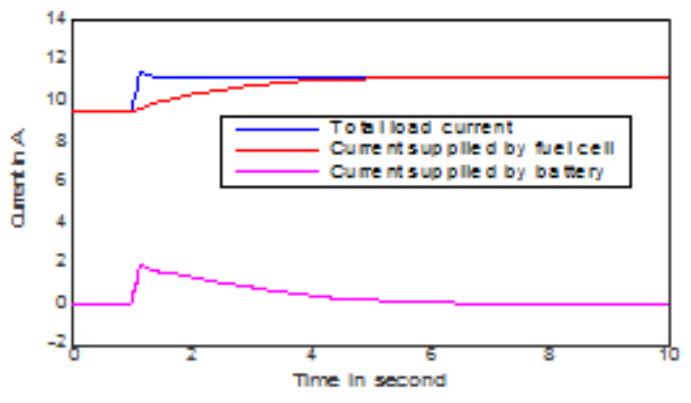

Figure 2. Total load current, current supplied by fuel cell, current supplied by battery

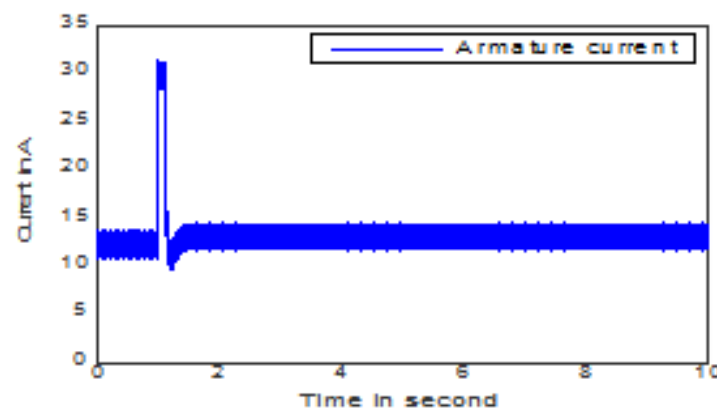

Figure 4. Armature speed 


\subsection{Prototype testing results}

The prototype is tested using an input which is varied from $6 \mathrm{~V}$ to $10 \mathrm{~V}$. A $9 \mathrm{~V}$ battery is also used. The seed of the motor is controlled by changing its duty cycle by using pulse with modulation. In Figure 5, power supplied by fuel cell is almost the same as total power demand from the load. In Figure 6, current supplied by fuel cell is almost the same as total load current (DC side) just like in Figure 5. From Figure 5. it can be observed that when the input voltage is higher than the battery voltage then the total current is supplied by the input as the speed of the motor increases. In Figure 6 it shows that when the input voltage is lower than the battery voltage then the total current is supplied by the battery when the motor speed in increased.

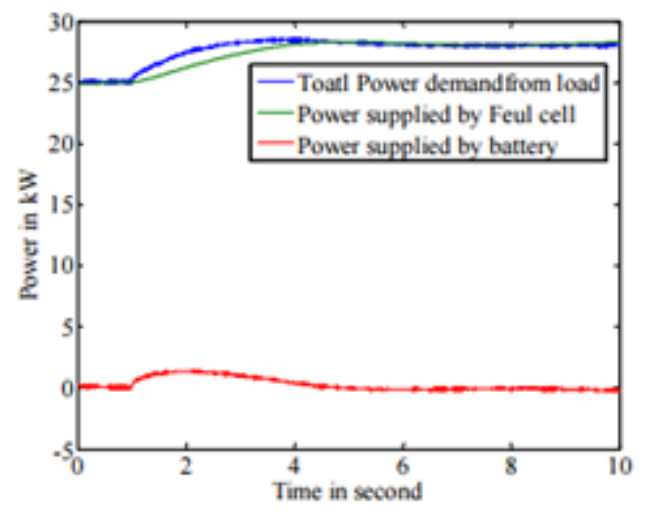

Figure 5. Power output from fuel cell, battery and total DC power for change of load

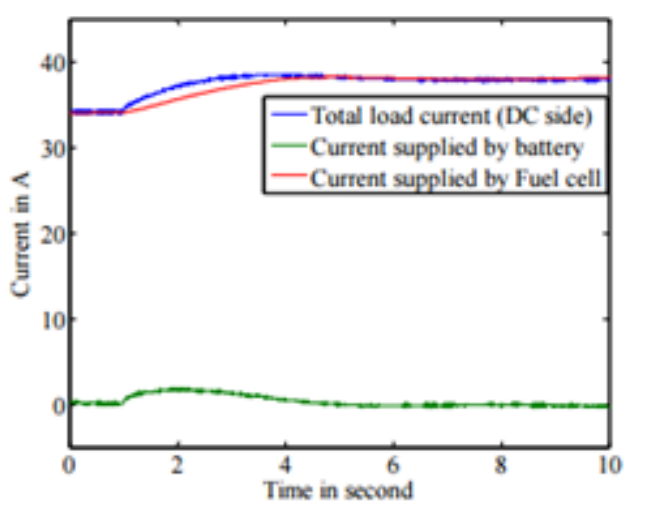

Figure 6. Fuel cell, battery and total DC current for change of load

From Figure 7, when the input voltage is lower than the battery voltage then the total current is supplied by the battery, but as the input voltage increases the input current increases and the battery current decreases at the same rate to maintain energy balance. Once the input voltage is more than the battery voltage the total current is supplied by the battery.

The power supplied by fuel cell DG is higher than the power requested from the load at the fourth second as shown in Figure 7. In Figure 8, the reactive power request started to be constant at 1 second, while the reactive power supplied by the fuel cell DG experiences the overshoot and undershoot until it reaches a steady state at above 6 second. Reactive power request from the load is constant from first second but reactive power supplied by fuel cell DG is constant from the sixth second.

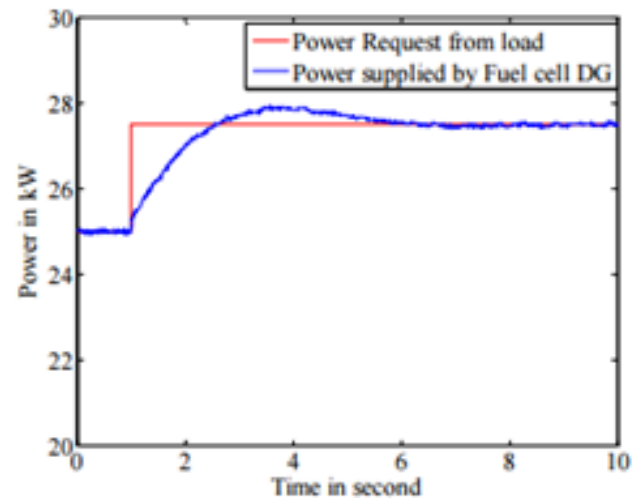

Figure 7. Tracking performance of fuel cell DG for sudden change of active power load

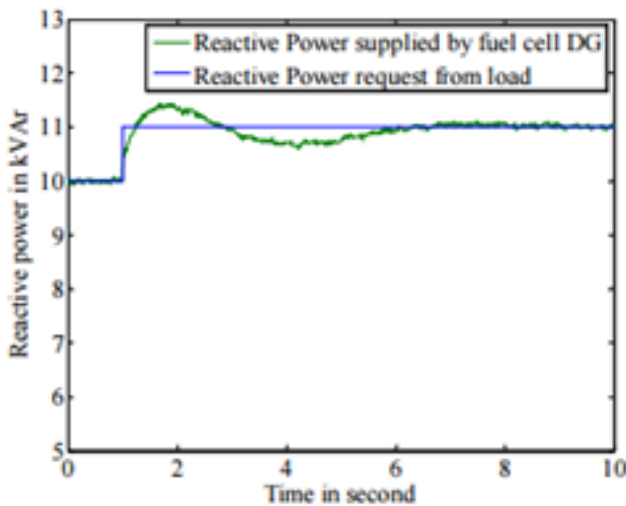

Figure 8. Tracking performance of fuel cell DG for sudden change of reactive power load

From Figure 9 and Figure 10, the actual current increased at the first second for Figure 9 whereas for Figure 10, it is decreased. The reference currents are the same. In Figure 11 and Figure 12, all the input currents and total currents increased gradually. For battery currents, it maintains the same which is 0 A throughout the process. 


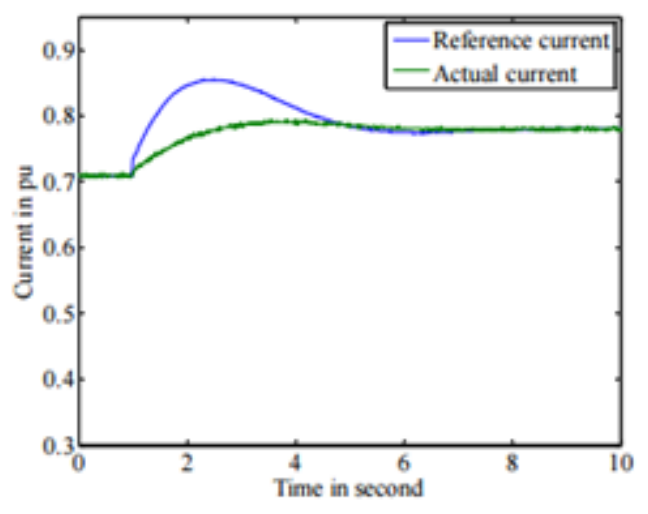

Figure 9. d-axis of dc/ac converter for change of load along with its reference current

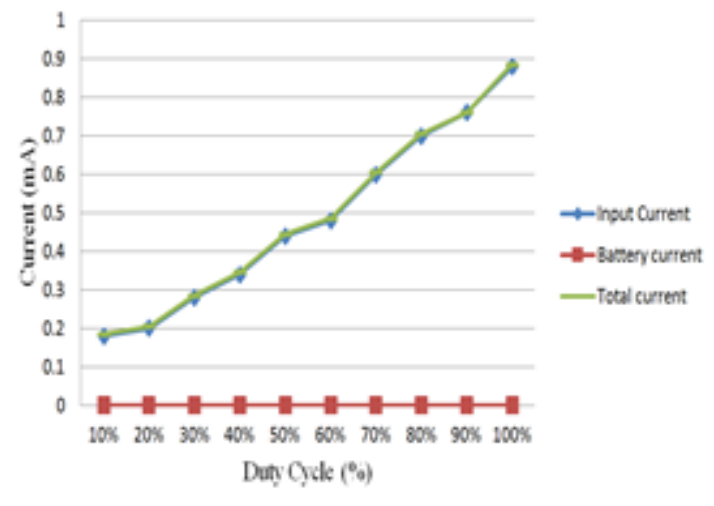

Figure 11. Total current vs battery current when input voltage is higher than battery voltage

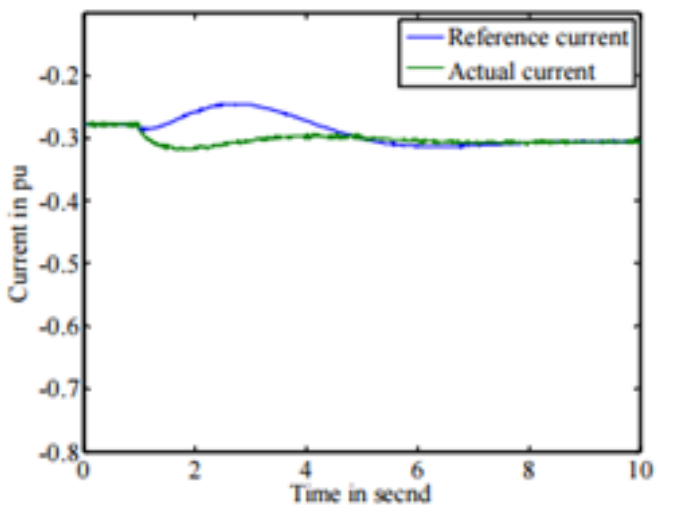

Figure 10. q-axis current of dc/ac converter for change of load along with its reference current

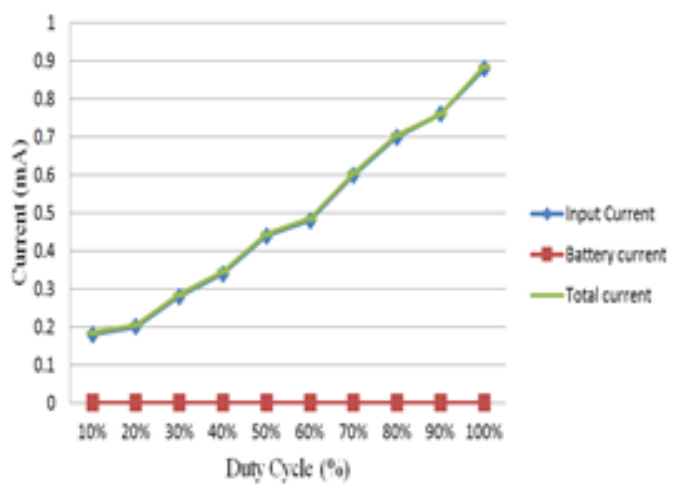

Figure 12. Total current vs input and battery voltage is higher than input voltage

Figure 13 illustrates the input current versus battery current. From this figure, the input current in $\mathrm{mA}$ for the batter decreases as the input voltage is increased. On the other hand, the input current is proportional with respect to the increment of the input voltage. This phenomenon has caused the total current to gradually increase with the increment of the input voltage of the system.

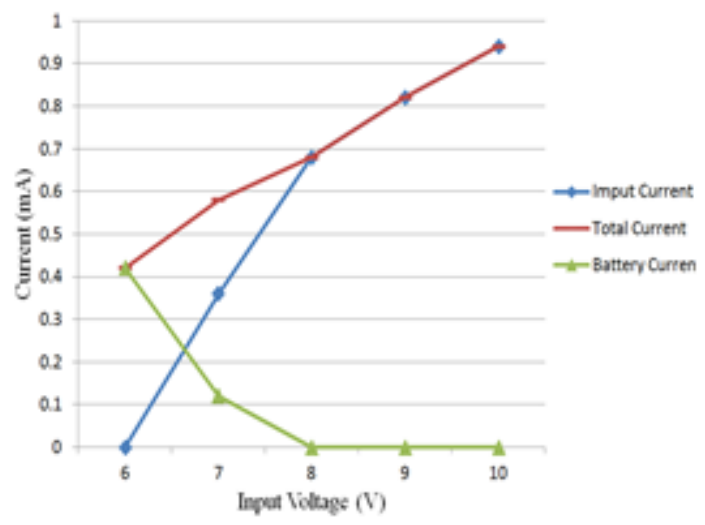

Figure 13. Input current vs battery current 


\section{CONCLUSION}

This paper has presented the experimental study on transient response of fuel cell. The dynamic behavior of the fuel cell has been simulated, modeled and tested in the laboratory. Hydrogen and reformer dynamics are considered as main part of the fuel cell modeling the fuel cell and dc/dc converts are modeled together as the controlled current sources. The transient current is supplied by the battery. The model and its controllers are simulated and tested in the laboratory for change in demand and found that their operations are satisfactory. Improvements can be made to improve the response time of the fuel cell.

\section{ACKNOWLEDGEMENTS}

The authors would like to acknowledge the Institute of Research Management and Innovation (IRMI), Universiti Teknologi MARA, Malaysia for the financial support. This study was supported by IRMI under the LESTARI Research Grant Scheme under the Project Code: 600-IRMI/DANA 5/3/LESTARI (0169/2016).

\section{REFERENCES}

[1] J. W. Patrick, "Handbook of fuel cells. Fundamentals technology and applications," Fuel, vol. 83, no. 4-5, p. 623,2004

[2] K. Sedghisigarchi and A. Feliachi, "Dynamic and transient analysis of power distribution systems with fuel Cellspart I: fuel-cell dynamic model," in IEEE Transactions on Energy Conversion, vol. 19, no. 2, pp. 423-428, June 2004

[3] K. Sedghisigarchi and A. Feliachi, "Dynamic and transient analysis of power distribution systems with fuel Cellspart II: control and stability enhancement," in IEEE Transactions on Energy Conversion, vol. 19, no. 2, pp. 429-434, June 2004

[4] S. Park, C. Chen and J. J. Lai, "A Wide-Range Active and Reactive Power Flow Controller for a Solid Oxide Fuel Cell Power Conditioning System," in IEEE Transactions on Power Electronics, vol. 23, no. 6, pp. 2703-2709, Nov. 2008

[5] M. Y. El-Sharkh, A. Rahman, M. S. Alam, A. A. Sakla, P. C. Byrne and T. Thomas, "Analysis of active and reactive power control of a stand-alone PEM fuel cell power plant," in IEEE Transactions on Power Systems, vol. 19, no. 4, pp. 2022-2028, Nov. 2004.

[6] C. Wang and M. H. Nehrir, "Load Transient Mitigation for Stand-Alone Fuel Cell Power Generation Systems," in IEEE Transactions on Energy Conversion, vol. 22, no. 4, pp. 864-872, Dec. 2007.

[7] M. H. Nehrir, C. Wang and S. R. Guda, "Alternative Energy Distributed Generation: Need for Multi-Source Operation," 2006 38th North American Power Symposium, Carbondale, IL, 2006, pp. 547-551.

[8] Y. Zhu and K. Tomsovic, "Development of models for analyzing the load-following performance of microturbines and fuel cells," Electr. Power Syst. Res., vol. 62, no. 1, pp. 1-11, 2002.

[9] M. Yamaguchi, T. Saito, M. Izumitani, S. Sugita and Y. Tsutsumi, "Analysis of control characteristics using fuel cell plant simulator," in IEEE Transactions on Industrial Electronics, vol. 37, no. 5, pp. 378-386, Oct. 1990.

[10] Jin-Woo Jung and A. Keyhani, "Fuel cell based distributed generation system," 2008 12th International Middle-East Power System Conference, Aswan, 2008, pp. 610-616.

[11] M. Y. El-Sharkh, A. Rahman, and M. S. Alam, "Neural networks-based control of active and reactive power of a stand-alone PEM fuel cell power plant," J. Power Sources, vol. 135, no. 1-2, pp. 88-94, 2004.

[12] K. -. Hauer, "Dynamic interaction between the electric drive train and fuel cell system for the case of an indirect methanol fuel cell vehicle," Collection of Technical Papers. 35th Intersociety Energy Conversion Engineering Conference and Exhibit (IECEC) (Cat. No.00CH37022), Las Vegas, NV, USA, 2000, pp. 1317-1325 vol.2.

[13] T. Vigneysh and N. Kumarappan, "Dynamic modeling and control of utility-interactive microgrid using fuzzy logic controller," in Lecture Notes in Electrical Engineering, 2018, vol. 446, pp. 97-106.

[14] A. Goel, S. Mishra and A. N. Jha, "Power Flow Control of a Solid Oxide Fuel-Cell for Grid Connected Operation," 2006 International Conference on Power Electronic, Drives and Energy Systems, New Delhi, 2006, pp. 1-5.

[15] Y. H. Li, S. S. Choi and S. Rajakaruna, "An analysis of the control and operation of a solid oxide fuel-cell power plant in an isolated system," in IEEE Transactions on Energy Conversion, vol. 20, no. 2, pp. 381-387, June 2005. 